\title{
牛乳中の血清アルブミンおよび免疫グロブリン $\mathrm{G}$ \\ の免疫学的定量
}

\author{
阿 部 恒夫 中 中野 光 志* \\ （農林省畜産試験場育種部，*千葉県農業共済組合連合会)
}

(1972. 1. 22 聚付)

正常な牛の乳汗中には血清アルブミンおよび免疫ダロ ブリンが微量に存在することが報告されており れらの含有量は生理的に变動し，とくに分娭前後の変動 が著るしく，初乳中には免疫グロブリンが選択的に移行 し増量していることが知られている3,4. 一方, 汹乳期 における乳汁中のこれら血清蛋白質の含有量法比较的 一定していると考无られているが，乳房炎の発生に伴 、5,6,7,8)，西るいは実験的に生理的食塩水を乳房内下注 入するなどの処置により一時的に血清蛋白質成分が増量 することが観察されている に㧍ける乳汁中の血清蛋白質の定量は，主として乳清を 電気泳動に上り分画し，各蛋白質の相対的な浱度比から 求妨れたものが多く，必ずしも微量な特定蛋白質の定 量法としてすぐれているとは言い難い。

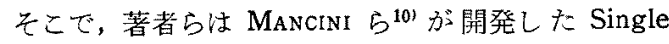
radial immunodiffusion 法に着目し，より簡便で正確 な牛乳中の血清アルブミンと免疫ダロブリンの免疫学的 定量法を検副し，あわせて正常乳および乳房炎乳におけ る測定値の比較裳行汸った。

\section{実 験 方 法}

\section{1. 供試乳およびその調整}

供試牛乳は，蓄産試験場およびその近郊で飼育されて いるホルスタイン種泌乳牛から採取した. 乳房炎の診 断は主として臨床的所見により行ない，乳汁の検查は CMT の改良法である PL テスト ${ }^{11}$ により行なった. 牛 乳は測定時まで $-20^{\circ} \mathrm{C}$ に凍結保存した。

乳清の調整は，牛乳を $3,000 \mathrm{rpm}, 10$ 分間遠心分離

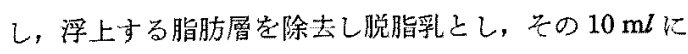
50 倍希釈のレソニン溶液 $0.1 \mathrm{~m} l$ 加光てよく混合し, $37^{\circ} \mathrm{C}$ に 20 分間静置してカゼインを㠜固させてからさら に遠心分離して透明な上清液を得た。乳房炎乳では, $\mathrm{pH}$ がフルカリ側になりカゼインの凝固が不完全になる
場合があるので，牛乳をあらかじ稀塩酸を用いて $\mathrm{pH}$ 6.0 調整してからレンニンを加えた.

2. 抗血清の調整

Bovine Serum Albumin (NBC, Lot. No. 8161, 以 下 BSA と略す) および Bovine IgG (Miles, Lot. No. 12 , 以下 IgG と略す) の各 $10 \mathrm{mg}$ 定 $1 \mathrm{~m} l$ の生理的食 塩水に溶解し，それぞれ机 FREUND's complete adjuvant (Difco) の等量安混合してクリーム状にした抗原

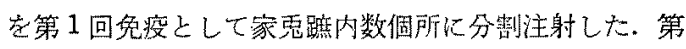
2 回免疫として 2 週間後见同量抗原老皮下注射した。第 2 回免疫 10 日後化試験採血行ない，十分な抗体量か 産生されていることを搉認して办方全放伹を実施し，血 清を分離した．各免度は3羽ずつの家无索用い，それぞ れの抗血清はプールしてから用いた．作製された抗一 BSA 拉よび抗-IgG の抗体亚は，沈降反应重層法に上る 測定ではそれぞれ 64 倍と 128 倍であった．以下の実験 における抗血清の希积は, Bacto hemoagglutination buffer pH 8.6 (Difco) を用いた。

\section{3. 绝没電気泳動法}

抗血清の特異性を検討するために，七ルローズ・アセ テート免疫電気泳動12)を行なった。通電条件性 $0.8 \mathrm{~mA} /$

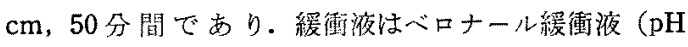
$8.6 ， 0.07 \mathrm{M}$ )を用いた. 抗原抗体反応は 48 時間行なっ た.

4. Single radial immunodiffusion 法

MANCINI ら $5^{101}$ の報告した方法簡易化し，以下の術式 で行なった.

抗血清一寒天ゲル平板の作り方: Bacto hemoagglutination buffer $100 \mathrm{~m} l$ を究角フラスコに入れ，これに Special agar-Noble (Difco) $3 \mathrm{~g}$ および防腐削として窒 化ソーダ $0.5 \mathrm{~g}$ を加え， $100^{\circ} \mathrm{C}$ 沸滕水中で約 20 分間加 熱溶解させ $3 \%$ 寒天溶液を作った。この場合，加熱中の 水分蒸発を防ぐためアルミ箔で三角フラスコの口をふさ 
いだ．溶解後の寒天溶液は必要量を大試験管にとり， $50^{\circ} \mathrm{C}$ 前後の恒温槽中に立て凝固を防止しておいた。つ いで，これにあらかじめ $50^{\circ} \mathrm{C}$ に加温されてある希釈抗 血清（本実験では，抗 BSA および抗 IgG はともに正 確に 20 倍に希釈した. ) を寒天液と等量混合し，抗血清一 寒天混合液它作り，恒温槽中に保った，つぎに，加温装 置付水平台におき暖められたガラス板上 $(10 \times 8.5 \mathrm{~cm})$ にゲルの厚さが $1 \mathrm{~mm}$ になるように正確に $8.5 \mathrm{ml}$ の前 記の抗血清一寒天混合液を注射筒を用いて手早く流し, 一様に広げて固まらせた．抗原孔として，直径 $2.5 \mathrm{~mm}$ の穴を金属管を用いて約 $2 \mathrm{~cm}$ の間隔でゲル板上に通常 は 15 個あけた。

検量曲線の作り方：抗原液の蛋白質含量はミクロ・ケ ルダール法により測定した. BSA については, 6.25, $12.5,25,50,100,200 \mathrm{mg} / \mathrm{d} l$ の 6 段階, IgG につい ては, $12.5,25,50,100,200,300,400 \mathrm{mg} / \mathrm{d} l$ の 7 段階の浱度の抗原希釈液各 $1 \mathrm{~m} l$ を作った。

それぞれをマイクロシリンジ (10 $\mu l$ 容量) を用いて $4 \mu l$ ずつ対応する抗体を含むゲル板上の抗原孔に入れ た. 抗原を入れたゲル板を, 湿潤密閉した容器に入れ, $37^{\circ} \mathrm{C} 72$ 時間水平に静置した. 反応は，24，48 および 72 時間後にゲル板をとりだし，抗原孔のまわりにでき た沈降輪の直径をバックを黑くし斜め下から光をあてた 観察箱の上で，カャリパスまたは/ギスを用いて測定し た. 各浱度の抗原につき 3 回測定の平均値を用い，横軸 に抗原量, 縦軸に沈降输直径の 2 平值をプロットして検 量曲線它作った.

試料中の BSA および IgG の定量：全乳あるいは乳 清の $4 \mu l$ を抗原孔に入れ, 反応の測定は 72 時間後に 1 回行なった．試料測定の同一ゲル板上には必ず標準抗原 液 3 点をおき，測定の正確さを確認した。

\section{実 験 成 績}

\section{1. 抗血清の特異性}

抗 BSA および抗 IgG の牛血清および乳清蛋白質に 対する反応性を免疫電気泳動法によって調バた. Fig. 1 に示されるように抗 BSA の反応は免疫原 (BSA), In 清および乳房炎乳清に対してのみ陽極側の同一易動度の 部分に単一の沈降線として琹められた。一方, 抗 IgGの 反応は免疫原 $(\mathrm{IgG})$, 血清抒よび乳房炎乳清に対して陰 極側に主な一本の沈降線として認められた。精製された $\alpha$-lactalbumin および $\beta$-lactoglobulin に対しては，い ずれの抗血清も反応を示さなかった。これらの成糾から 作製された抗血清は，BSA と IgGに対してそれぞれ 特異性を示すことが明らふにされた。

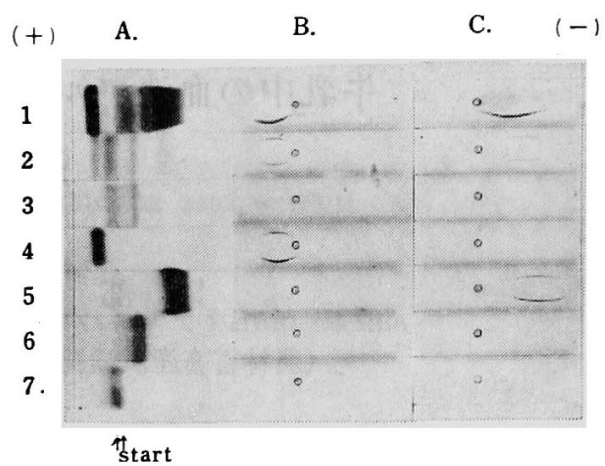

Fig. 1. Cellulose acetate electrophoretic and its immunoelectrophoretic patterns of bovine serum and whey proteins in normal and mastitic milk

A. electrophoretic pattern

B. immunoelectrophoretic patterns by using AntiBSA

C. immunoelectrophoretic patterns by using AntiIgG

1. blood serum

2. mastitic whey

3. normal whey 5. b Jvine $\mathrm{IgG}$

4 . bovine serum albumin (BSA)

( I )

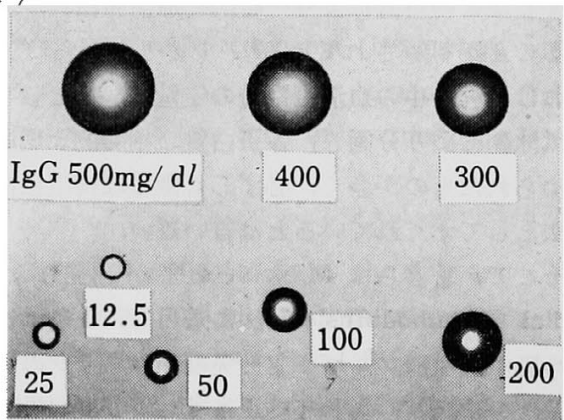

(II )

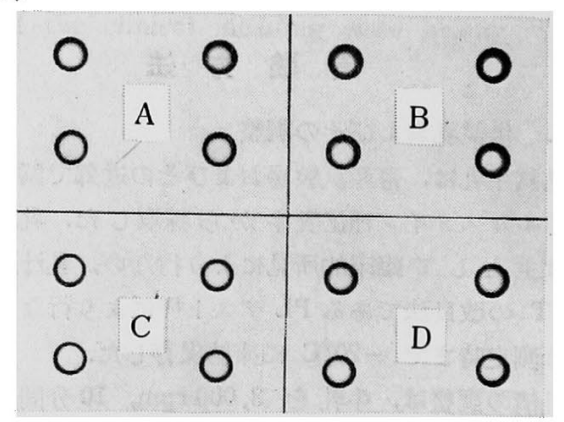

Fig. 2. Stained immunodiffusion plate

(I) The agar contained anti-IgG. The antigen wells were filled with serial dilution of bovine IgG.

(II) Block-wise arrangement of sixteen antigen wells in a diffusion plate. The all antigen wells were filled with the same amount of IgG to test intraplate variation. 


\section{2. 検量曲線执よび測定誤韭の検訶}

Fig. 2-(I)，Fig. 3 および Fig. 4 は，一定量の抗 BSA または抗IgG を含さ寒天ゲル板に小孔をあけ，こ の中に各濃度の一定量の抗原定分注して拡散させた場合

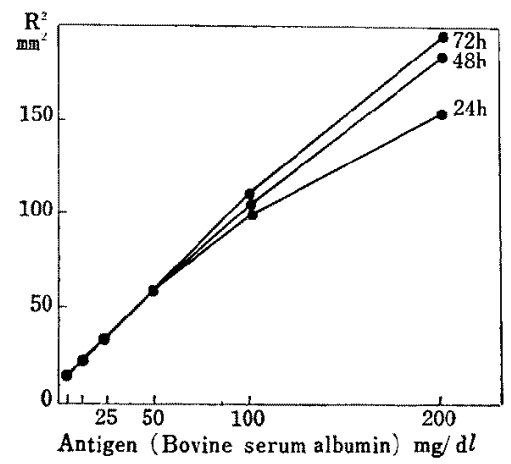

Fig. 3. Relation between square of diameter of precipitate ring and amount of antigen (Bovine serum albumin) after different times of diffusion

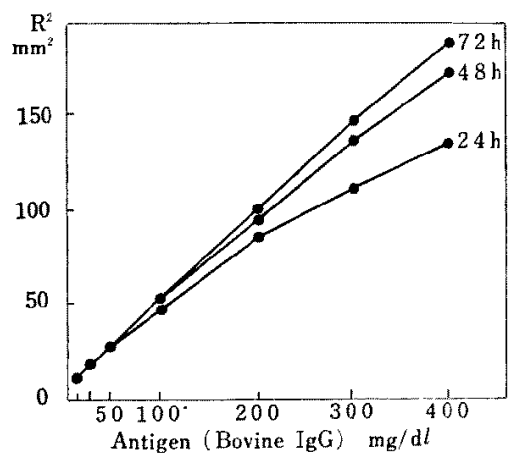

Fig. 4. Relation between square of diameter of precipitate ring and amount of antigen (Bovine IgG) after different times of diffusion

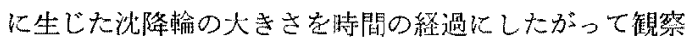
した成縝である。沈降輸の大きさは，測定上の簡便さか ら直経の二乘值 $\left(\mathrm{R}^{2}\right)$ であらいした。 た使用した抗 体浱度は，予供試験の結果加方寒天内最終浱度として $2.5 \% の$ 割合で原抗血清を含えでいることが牛乳中の BSA およびIgGの定量に最適であること学確認した。

抗 BSA の場合は，Fig. 3 に示されるように抗原量 が $6.25 \sim 100 \mathrm{mg} / \mathrm{d} l$ の籍国では，72時間後に生じた沈 降輸の $\mathbf{R}^{2}$ と抗原量との間に完全な比例関係が認められ た. $200 \mathrm{mg} / \mathrm{d} l$ 以上の抗原量で恃 72 侍間後に颃いても 反心应結していないで，その $\mathrm{R}^{2}$ 值は直線上にのって W\%以。

一方，抗 IgG の場合は Fig. 4 に示されるように抗 原量が $12.5 \sim 300 \mathrm{mg} / \mathrm{d} l$ の範团で完全な比例䦭係が成 立した，以上の成維から，こ狄らの検些曲線を用いて前 記の籍国内で牛乳中の BSA および IgG 含量を試料学

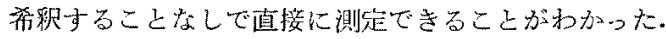

つぎに，測定值が寒灭平板間方よず同一平板内の抗原 の位䈯間でどれにどの差買があるが是検討するたるに，

Fig. 2-(II) に示したように，A，B，C，Dの4区分に 各 4 個，計 16 個の抗原孔配列した寒天平板 4 枚を作 留し，一定量の抗原をすべての抗原孔に注入し，得られ た測定値の分散分析を行なった。 その結果，Table 1 に 亦されるように平板間执よび抗原孔位置（A，B，C，D 間）による分散の值恓，平板・位置内の反復による誤差 分敞に比較して有意に大きいとはい光なかった。また則 定值の変動係数はわずかに $2.1 \%$ 程度に過ぎなかった。

以上の成縜から，測定值は平板㧍よび抗原孔の位置に

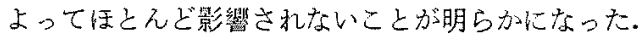

3. 正管乳㧍よび乳房炎乳中の血清フルブミン(BSA) と IgG 含腤

正常乳 27 例の平坞 BSA 合墨は $14.28 \pm 3.14 \mathrm{mg} / \mathrm{d} l$ であった。これにくらべて，乳房の嘾床所見とPLテス

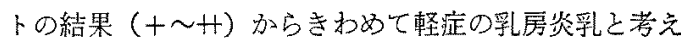

Table 1. Statistical analysis of inter-plate and intra-plate variation

\begin{tabular}{|c|c|c|c|c|c|}
\hline $\begin{array}{c}\text { Source of } \\
\text { variance } \\
\text { (S.V.) }\end{array}$ & $\begin{array}{c}\text { Degrees of } \\
\text { freedom } \\
\text { (D.F.) }\end{array}$ & $\begin{array}{c}\text { Sum of } \\
\text { squares } \\
\text { (S.S.) }\end{array}$ & $\begin{array}{c}\text { Mean } \\
\text { squares } \\
\text { (M.S.) }\end{array}$ & $\begin{array}{l}\text { Variance } \\
\text { ratio } \\
\text { (F) }\end{array}$ & $\mathbf{P}$ \\
\hline Between plate & 3 & 1.2730 & 0.4243 & 0.8245 & $\doteqdot 0.50$ \\
\hline Between position (within plate) & 12 & 5.6733 & 0.6394 & 1.2425 & $\doteqdot 0.25$ \\
\hline $\begin{array}{l}\text { Between replication } \\
\text { (within plate and position) }\end{array}$ & 48 & 24.6985 & 0.5146 & & \\
\hline Total & 63 & 33.6448 & & & \\
\hline
\end{tabular}

Standard deviation $=0.7308$

Coefficient of variation $=2.1069 \%$ 


\section{阿部・中野}

Table 2. Amounts of serum albumin (BSA) and immunoglobulin G (IgG) in normal and mastitic milk

\begin{tabular}{|c|c|c|c|c|c|}
\hline \multirow{2}{*}{ Group } & \multirow{2}{*}{$\begin{array}{c}\text { Sample } \\
\text { No. }\end{array}$} & \multicolumn{2}{|c|}{ BSA in } & \multirow{2}{*}{$\begin{array}{l}\operatorname{IgG} \text { in } \\
\text { whey }\end{array}$} & \multirow{2}{*}{ PL-test } \\
\hline & & whey & milk & & \\
\hline \multirow{13}{*}{ Mastitic milk } & & $\mathrm{mg} / \mathrm{d} l$ & $\mathrm{mg} / \mathrm{d} l$ & $\mathrm{mg} / \mathrm{d} l$ & \\
\hline & 1 & 23.4 & - & 124.6 & $+t$ \\
\hline & 2 & 41.8 & - & 214.4 & $H$ \\
\hline & 3 & 33.9 & - & 137.9 & $H$ \\
\hline & 4 & 35.3 & - & 253.6 & $H$ \\
\hline & 5 & 31.4 & - & 101.4 & $H$ \\
\hline & 6 & 39.0 & 37.5 & 195.0 & $H$ \\
\hline & 7 & 24.3 & - & 108.5 & + \\
\hline & 8 & 27.8 & - & 111.2 & + \\
\hline & 9 & 23.5 & 23.5 & 66.0 & + \\
\hline & 10 & 24.0 & 25.0 & 100.0 & + \\
\hline & Ave. & 30.44 & 28.67 & 141. 26 & \\
\hline & S.D. & \pm 6.8533 & \pm 7.6866 & \pm 59.7017 & \\
\hline \multirow{29}{*}{ Normal milk } & 1 & 21.5 & 19.0 & 142.5 & - \\
\hline & 2 & 14.0 & 17.0 & 90.1 & - \\
\hline & 3 & 15.5 & 15.5 & 97.2 & \pm \\
\hline & 4 & 17.0 & 17.0 & 106.4 & - \\
\hline & 5 & 10.0 & 13.0 & 48.7 & - \\
\hline & 6 & 15.5 & 15.0 & 130.0 & - \\
\hline & 7 & 16.5 & 17.4 & 82.3 & - \\
\hline & 8 & 13.5 & 14.5 & 84.2 & - \\
\hline & 9 & 11.5 & 11.5 & 38.8 & - \\
\hline & 10 & 9.5 & 13.5 & 42.5 & \pm \\
\hline & 11 & 12.5 & 11.5 & 60.2 & - \\
\hline & 12 & 14.5 & 15.0 & 66.8 & - \\
\hline & 13 & 11.5 & 11.5 & 64.0 & - \\
\hline & 14 & 9.5 & 10.0 & 97.1 & - \\
\hline & 15 & 15.0 & 15.0 & 44.3 & - \\
\hline & 16 & 13.0 & 11.5 & 76.1 & - \\
\hline & 17 & 14.0 & 15.0 & 54.6 & - \\
\hline & 18 & 15.5 & 15.5 & 53.2 & - \\
\hline & 19 & 17.0 & 17.0 & 63.8 & - \\
\hline & 20 & 21.0 & 22.0 & 90.2 & - \\
\hline & 21 & 12.5 & 13.4 & 108.0 & - \\
\hline & 22 & 10.0 & 12.5 & 60.3 & - \\
\hline & 23 & 15.5 & 15.5 & 60.8 & - \\
\hline & 24 & 17.0 & 15.5 & 78.0 & - \\
\hline & 25 & 11.5 & 12.5 & 51.5 & - \\
\hline & 26 & 13.5 & 14.0 & 49.2 & - \\
\hline & 27 & 17.5 & 16.5 & 42.0 & - \\
\hline & Ave. & 14.28 & 14.71 & 73.44 & \\
\hline & S. D. & \pm 3.1389 & \pm 2.6339 & \pm 27.2653 & \\
\hline
\end{tabular}

られた 10 例の平均 BSA 含量は $30.44 \pm 6.85 \mathrm{mg} / \mathrm{d} l$ であ り，正常値の 2 倍以上の值が示され，両者の差は $1 \%$ 水 準で有意であった（Table 2)。また乳清を用いたBSA測 定値と全乳のままで測定した值の相関係数は $\mathrm{r}=0.9713$ であり，きわめて高い有意な相関関保が認められた。こ
のことは乳中のBSA 含量の変動を追求する場合、全乳で 測定してる乳清の測定と大差のないことを示している. 乳清中の IgG 合量怯, 正常乳では $73.44 \pm 27.27 \mathrm{mg}$ / $\mathrm{d} l$, 乳房炎乳で梳 $141.26 \pm 59.70 \mathrm{mg} / \mathrm{d} l$ であり, $\mathrm{BSA}$ 含量と同様に乳房炎乳で明らかに高い值であった。しか 
しそのバラッキはBSA 含量のをれよりも大きかった。 また乳清中の BSA 含量 $(\mathrm{X})$ と IgG 合量 $(\mathrm{Y}) と の$ 間には， $\mathrm{r}=0.8072$ という有意な相関関係が認められ， 両者の間に $\mathrm{Y}=4.6278 \mathrm{X}+3.78$ という回归式が求めら れた。

\section{考察}

この実験の電気泳動により認められた乳清中の主な蛋 白質は, serum albumin, $\beta$-lactoglobulin, $\alpha$-lactalbumin 拉よび immunoglobulin の4つであった. 正常 乳に执いて 量的に最も多いのは $\beta$-lactoglobulin であ り,つWで $\alpha$-lactalbumin であった。これら2者は， 電気泳動の易動度および抗原性からも明らかに血清蛋白 質と異り，乳腺で新たに合成された㔻白質である行，14． 一方, serum albumin (BSA) と immunoglobulin は, 直接直中加ら移行したものと考えられている，この実䮦 においても，乳清中の BSAの易動度抢よび抗原性は 血清中のむのと同一であった。 しかし, 乳清中の immunoglobulin についてはその抗原性注血清中のそれ之 共通性が示されていたが，易動度は血清中の子のとやや 異なっていた。この理由としては次のように考光られ る.すなわち, 牛の $\operatorname{IgG}$ は $\mathrm{IgG}_{1}$ と $\mathrm{IgG}_{2}$ の 2 の subclass に分けられ沾，16)，血清中には $\mathrm{IgG}_{2}$ が主体であ り，乳中には主として易動度の速い $\mathrm{IgG}_{1}$ が移行するこ とが知られているのに伍，本実験においては IgG $\mathrm{IgG}_{2}$ と堂区別しないで結果をみたためであらう。

このように血清蛋白質の乳中八の移行については，避 択的移行が考えられ，上くに初乳においては IgG 行が主体であり，血清丁ルブミン， $\mathrm{IgG}_{2}$ その他血清蛋 白質の移行は少ないことが知られている17，しかし，乳 房炎の諸種の経過にともなう乳中への血清蛋白質の移行 のパターンについては詳細は不明であり，その解明は乳 房炎の診断・治療上に有益な情報を与えるものと考え る.

また本法による血清㔻白質の定量壮，検乳の前好置お よび特殊な則定機器を必要々せず, 多数の検体を保存し 同時に測定できるので，今後乳房炎診断基準としての BSA およびIgG 含量ならびに他の骖断法との関連性な ぞが明らかにされれば害用的意義が大きいるの考支る。

\section{結論}

牛血清アルブミン (B SA) および免疫グロプリン （IgG）を抗原として家鬼を在疫して得た抗血清を用い $\tau$, Single radial immunodiffusion 法により牛乳中の 血清成分を定量する方法を検討し，つぎの結果を得た。
1) 作製された抗 BSA および抗 IgG は，それぞれ の抗原とのみ特異的に反応し，乳清中の他の蛋白質成分 である $\alpha$-lactalbumin， $\beta$-lactoglobulin などと交又区 応宏全く示さないことが確認された。

2)これらの抗血清客用いて，寒天中の抗血清濃度它 $2.5 \%$, 検体容量 $4 \mu l$ とし, $37^{\circ} \mathrm{C}$ で 72 時間後に生じ た沈降輸の直径の二乘值之搔体中の抗原量（BSA だは $6.25 \sim 100 \mathrm{mg} / \mathrm{d} l$ の範囲, IgG では $12.5 \sim 300 \mathrm{mg} / \mathrm{d} l$ の 範囲）との間に完全な比例関係が成立した。 をた測定值 の变動係数は $2.1 \%$ であった：これらの検量曲線を用い て，牛乳中の BSA および IgG 原液のままで極めて 容易に定量することが可能であった。

3）この方法により測定された正常乳中のBSA の平 均含量は $14.28 \pm 3.14 \mathrm{mg} / \mathrm{d} l, I g G$ 含量は $73.44 \pm 27.27$ $\mathrm{mg} / \mathrm{d} l$ であった．臨床的に軽度の乳房炎乳に拉けるこ

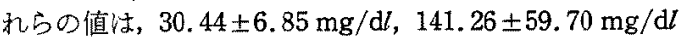
ですり，いずれの成分も正常乳にくらべて明らかに增量 していることが認められた。

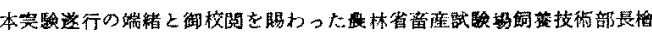

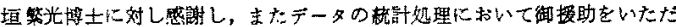

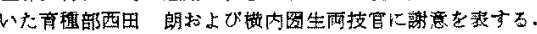

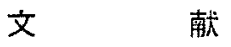

1) Peskett, G.L. (1932) Annual Report of the National Institude of Dairying Reading, 52-53.

2) Rose, D, J.R. Brunner, E. B. Kalan, B. L. Larson, P. Melnychyn, H.E. Swaisgood and D. F. W AUGH (1970) J. Dairy, Sci. 53: 1-17.

3) LaRson, B.L., and K. A. Kendall (1957) J. Dairy Sci., 40: 659-666.

4) PORTER R.M. and H.R. Conrad (1967) J, Dairy Sci., 50: 505-508.

5) Lecce J.G. and J.E. Legates (1959) J. Dairy Sci., 42: 698-704.

6) Shah, P.C., G.E. Morse and D.H. Pitikin (1963) Am. J. Vet. Res., 24: 723-729.

7）清水高正・永友筧司（1970）宮大農報 17：186196.

8) Carroll, E.J., O.W. Schalm and J. Lasmanis (1963) J. Dairy Sci., 46: 1236-1242.

9) Grajewska, P. (1970) Bull. vet. Inst. Putawy 14, 52-58. (Dairy Sci., abstr. (1971) 33: 4248)

10) Mancini, G., A.O. Carbonara and J.F. HeErman (1965) Immunochem., 2: 235-254.

11) 桐次 統・兼清知彦 (1958) 日本临医師会雑誌 11; 481-483.

12）小川恕人（1965）代謝 2: 514-532.

13) Larson, B.L. and D.C. Gillespie (1957) J. Biol. Chem., 227: 565-568. 
14) Gerristen, G. C. (1963) Diss. Abstr., 23: 52.

15) Gray, G.D., M. M. Mickelson and J. A. Crim (1969) Immunochem., 6: 641-644.

16) Milstejn, C.P. and A, Feinstein (1968) Bio- chem., J., 107: 559-564.

17) Murphy, F. A., O. Aolound, I. W. Osedold and E. J. Carroll (1964) Archs Biochem. Biophys. 108: $230-239$.

\title{
Résumé
}

Immunological quantitation of serum albumin and IgG immunoglobulin in bovine milk

\author{
Tsuneo ABE and Terushi NaKano* \\ (Department of Animal Breeding, National Institute of Animal \\ Industry, Chiba, *Section of Animal Insurance, Federation \\ for Agricultural Mutual Relief of Chiba Prefecture)
}

Single radial immunodiffusion technique was employed for quantitation of the serum albumin (BSA) and IgG immunoglobulin in bovine milk. Two kinds of antisera, anti-BSA and anti-IgG, were prepared by immunizing rabbits with the corresponding antigens plus Freund's complete adjuvant.

It was confirmed that these antisera reacted only with the corresponding antigens, and did not crossreacted with $\alpha$-lactalbumin, $\beta$-lactoglobulin and the other proteins in milk.

When $4 \mu l$ of an antigen solution of an unknown concentration is allowed to diffuse from a well in a thin layer of agar gel containing the antiserum in the ratio of 2.5 per cent of its original concentration at $37^{\circ} \mathrm{C}$ for 72 hours, the square of diameter of final precipitate ring is directly proportional to the amount of antigen employed. By using this system, the amount of BSA ranged from $6.25 \sim 100 \mathrm{mg} / \mathrm{d} l$ and $\mathrm{IgG}$ ranged from $12.5 \sim 300 \mathrm{mg} / \mathrm{d} l$ in milk were measured directly without any pretreatment of samples. The cofficient of variation of the measurements to an amount of antigen was less than 2.5 per cent.

It was also shown that the average BSA contents in normal milk was $14.28 \mathrm{mg} / \mathrm{d} l$ and that of IgG was $73.44 \mathrm{mg} / \mathrm{d} l$, and the mastitic milk contained much more BSA and IgG as compared with normal milk. 